\title{
Dance and Its Importance in Bach's Suites for Solo Cello
}

Audrey Hebson

Cedarville University, audreyhebson185@cedarville.edu

Follow this and additional works at: https://digitalcommons.cedarville.edu/musicalofferings

Part of the Musicology Commons

DigitalCommons@Cedarville provides a publication platform for fully open access journals, which means that all articles are available on the Internet to all users immediately upon publication. However, the opinions and sentiments expressed by the authors of articles published in our journals do not necessarily indicate the endorsement or reflect the views of DigitalCommons@Cedarville, the Centennial Library, or Cedarville University and its employees. The authors are solely responsible for the content of their work. Please address questions to dc@cedarville.edu.

\section{Recommended Citation}

Hebson, Audrey (2010) "Dance and Its Importance in Bach's Suites for Solo Cello," Musical Offerings: Vol. 1 : No. 2 , Article 2.

DOI: 10.15385/jmo.2010.1.2.2

Available at: https://digitalcommons.cedarville.edu/musicalofferings/vol1/iss2/2 


\section{Dance and Its Importance in Bach's Suites for Solo Cello}

\section{Document Type}

Article

\section{Abstract}

Before J. S. Bach, the cello was rarely used as a solo instrument. With his suites for solo cello, however, Bach took the instrument out of the background of dance accompaniment and basso continuo, and placed it on the center stage for musical audiences. He accomplished this by using dance movements, a style in which the cello was already a familiar accompanying instrument. The forms of these dance movements were also used in such a way as to uniquely express the cello's potential as a solo instrument. Ultimately, it was these suites that would inspire other composers to write solo works for the cello. By looking to the past, Bach created a work that looked to the future. This paper explores the musical elements in this work that contribute to their lasting influence.

\section{Keywords}

Bach, cello suites, dance

\section{Creative Commons License}

\section{(c) (1) $9 \Theta$}

This work is licensed under a Creative Commons Attribution-Noncommercial-No Derivative Works 3.0 License. 


\title{
Dance and Its Importance in Bach's Suites for Solo Cello
}

\author{
Audrey Hebson \\ Cedarville University
}

J ohann Sebastian Bach's works have become the foundation of musical understanding for nearly all of the main instruments used today. His immense harmonic vocabulary, through counterpoint and other mechanisms, is unmatched by any in the Baroque period. Using this harmonic vocabulary, Bach could masterfully exploit the virtuosic capabilities of the instrument for which he was composing, whether he was demonstrating the many voices of a fugue for piano, or the counterpoint possible in the solo line of a flute sonata. On the other hand, Bach was fascinated by dance, and this fascination can also be clearly seen throughout many of his pieces. Bach wrote many dance suites for a variety of instruments, showing off his comprehension of the many different dance styles that were in vogue during his time. Nowhere is the union of these two ideas, Bach's virtuosity and his fascination with dance, seen more clearly than in his six suites for unaccompanied violoncello. Before Bach, the cello was rarely, if ever, used as a solo instrument. With these suites, he took the cello out of the background of dance accompaniment and basso continuo, and placed it on the center stage for musical audiences. He accomplished this by using dance movements, a style in which the cello was already a familiar instrument to the public, as it was often used to accompany court dances. The forms of these dance movements were also used in such a way as to uniquely express the cello's potential as a solo instrument. Ultimately, it was these suites that would inspire other composers to write solo works for the cello. Bach, then, brilliantly uses dance in his solo cello suites as a channel through which to introduce the cello as a valuable solo instrument. Many factors combined to create a work that made an immense impact on the repertoire for cello, and the following paragraphs will examine these factors, most notably, Bach's focus on dance and his use of various contrapuntal and rhythmic techniques.

Before Bach, the cello was considered to be, for the most part, an accompanying instrument, and did quite well in this capacity. It was generally used as part of the basso continuo or obbligato part of a piece or as dance accompaniment. Suzanne Wijsman states, "In Austria and Germany the cello appears to have been used primarily in dance music, or as a part of the continuo group to reinforce the bass or to play obbligato parts. It did not gain a more independent role until the second half of the eighteenth century" (Wijsman, 755). Often, when providing an accompaniment as a basso continuo, the cello would be joined by a chordal instrument, like a harpsichord or lute. Additionally, another cello would provide the other notes in the chord necessary to produce adequate accompaniment (Markevitch, 1). Many composers hailed the cello as being the most prominent 
instrument for accompaniment, as is evidenced by Dmitry Markevitch, who quotes the method book of Baroque composer Michel Corrette:

If all countries give preference to the cello to play the basso continuo, it is not without reason, the bass being the foundation of harmony...[T]he cello satisfies ears sensitive to harmony. Also voices are charmed to be accompanied by it, realizing that nothing makes them shine like the accompaniment of this sonorous instrument which articulates so well its tones and speaks so distinctly; so different from the instruments which only make cymbal-like and nasal sounds to which it is necessary to ask each minute the name of the note which they have just played, the ear having heard only a confused noise which forbids hearing all the beauty of the harmony of which the bass is the principal object (Markevitch, 1).

As dance accompaniment, the cello also excelled. It was often used in social dance settings (Mellers, 16), as it was more portable than the harpsichord. Its ability to create resonant tone with clear articulation made it ideal for the variety of dances that were used in the courts of the time. This dance music also allowed the cellist to showcase his improvisational skills, producing variations on the melodic themes used in the various dances. Bach, then, would have seen the possibilities that were available to him in writing for cello when attending the social dances of the day.

Dance was one of the main social functions of the Baroque period, giving the cello a large amount of exposure. French court dancing was a symbol of French culture, promoted vigorously during the reign of Louis XIV, who loved aristocratic dancing (Little, 4). Many functions in French culture involved dance, from ballet to grand balls to simple social dances. Much of the French dance style carried over to other countries as well, and courts all over Europe experienced the joys of French and Italian style dances. In fact, in order to keep up with the times, many German courts would hire French dance instructors to teach the different movements to their court members, as dancing ability was a requirement in European court life (Little, 9). In the words of Chiapusso, "During Bach's time in the unique atmosphere of French court life, the dance was more than a mere etiquette: it portrayed the most refined graces of the soul, expressing devotion and reverence for the Roi Soleil, the highest embodiment of idealism" (159). Therefore, the cello had many performance opportunities as dance accompaniment during the Baroque era.

This emphasis on dance throughout the Baroque era had a very profound impact on Bach's music, as can be seen in the solo cello suites. These suites were written 
during his time at Cöthen. Cöthen was a different venue for Bach, in that it was more secular than his other residencies. As Wolff states, "While performances of music at the palace church service, for example, played a major role in Weimar, sacred music was clearly of secondary importance at the reformed Cöthen court" (195). This court held many dances, which enabled Bach to observe all the popular dance styles of the time. Bach was passionate about dance - "Bach recognized the universal power of the dance to lift man's spirit to extravagant and apparently irrational realms of self-identity" (Chiapusso, 158).

Bach's knowledge of dance can be clearly seen in his cello suites. He uses many of the popular dance styles, from the French, Italian, and German styles. The allemande, originally a German dance, is a very stately flowing dance, and appears in all six of the suites. The courante is a French dance, is generally considered to have a slow tempo, and also occurs in the fifth cello suite (albeit at a faster tempo than in the actual dance) (Little, 115). Correntes are in all the other suites besides the fifth suite, and are Italian dances that are bright, vigorous, and cheerful (Little, 139). The sarabande, another common fixture of all six suites, is Italian in origin and has a very noble, balanced, sustained feel (Little, 92). Two of the suites contain bourées in pairs, which are French lighthearted dances (Little, 35). In place of the bourées, gavottes are in pairs in two suites, which are fairly moderate with a pastoral feel (Little, 47). The two remaining suites each contain a minuet, which was an extremely popular French social dance with varying ideas of tempo (Little, 62). The last movement in each suite is a gigue, a "lively and spritely" French dance (Little, 144). All of these dances were popular during Bach's time, and therefore would have been very familiar to any audience.

While the solo cello suites were not intended to accompany a dance, one can see many of the dance elements Bach strategically placed into the dance movements of the suites. Bach does not give the suites the penetrating energy he used when composing his works for solo violin; rather, he gives them a sense of serenity and grandeur, which fits with the idea of courtly dance (Spitta, 97). From a more technical aspect, though, Bach uses specific rhythmic ideas to illustrate the ideas of the different dances.

In the bourees, for example, the dance is characterized by a strong upbeat, and Bach accentuates this by ensuring that all the bowings in the bourées of the Anna Magdelena Bach manuscript indicate a separation between the upbeat and downbeat (Little, 45).

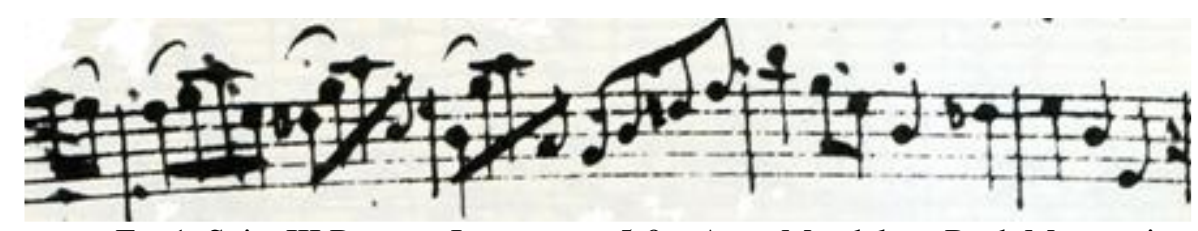

Ex. 1, Suite III Bourree I, measures 5-9 - Anna Magdalena Bach Manuscript 
As you can see from this example, the first three notes of each eight-note grouping are slurred, and the last eighth note is played separately, indicating this upbeat and downbeat separation.

The gavottes, which are danced with high, rhythmic leaps, are demonstrated with slurs in two and four-note groupings which sometimes emphasize either the beat or the pulse (Little, 60). This is evidenced by the two and four-note groupings in the following example.

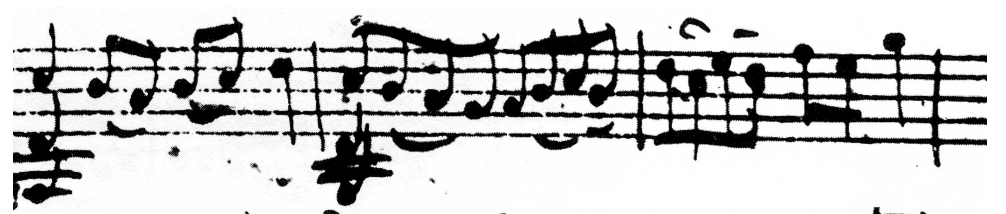

Ex. 2, Suite VI Gavotte I, measures 17-19 - Anna Magdalena Bach Manuscript

The minuet is characterized by one four measure phrase followed by another, stronger, four-measure phrase. This is demonstrated by slurs which emphasize the larger unit phrases.

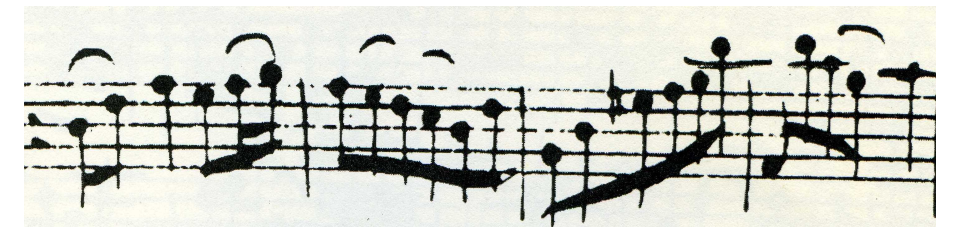

Ex. 3, Suite I Minuet I, measures 9-12 - Anna Magdalena Bach Manuscript

The sarabande is generally considered to be turbulent in nature, and its syncopated rhythm is the foundation of the phrases of these movements in the suites. In the following example, one can see dotted rhythms and notes tied over bar lines, illustrating syncopation.

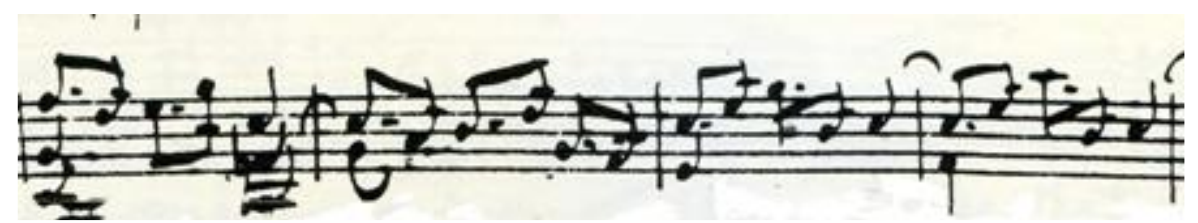

Ex. 4, Suite IV Sarabande, measures 23-26 - Anna Magdalena Bach Manuscript

However, Bach experiments with different rhythms by removing this syncopation altogether in Suite V (Little, 107).

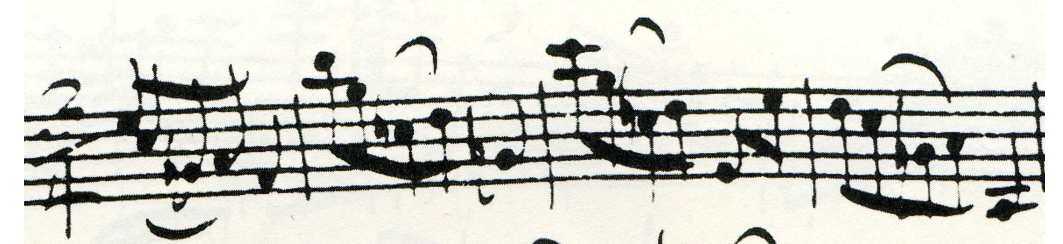

Ex. 5, Suite V Sarabande, measures 1-4 - Anna Magdalena Bach Manuscript. 
In a courante, the dancers move in step-units that cross bar lines, and this is demonstrated in this movement in the fifth cello suite.

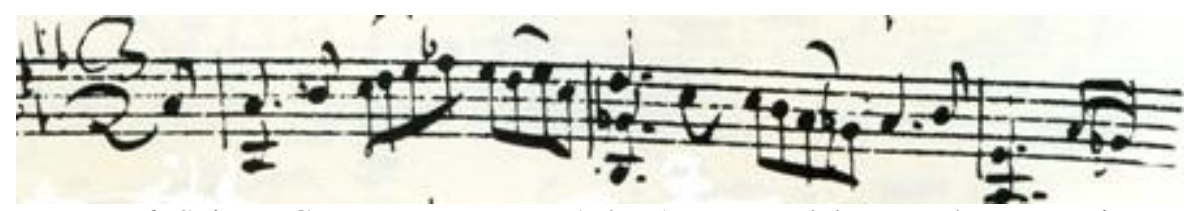

Ex. 6, Suite V Courante, measures 1-4 - Anna Magdalena Bach Manuscript

The correntes (called courantes, but in corrente style) in the cello suites have irregular bowing patterns, which emphasize the lively nature of the dances. The bowing patterns in the following example are very irregular, sometimes covering more than one measure, and sometimes separating either the first or last note in a bar.

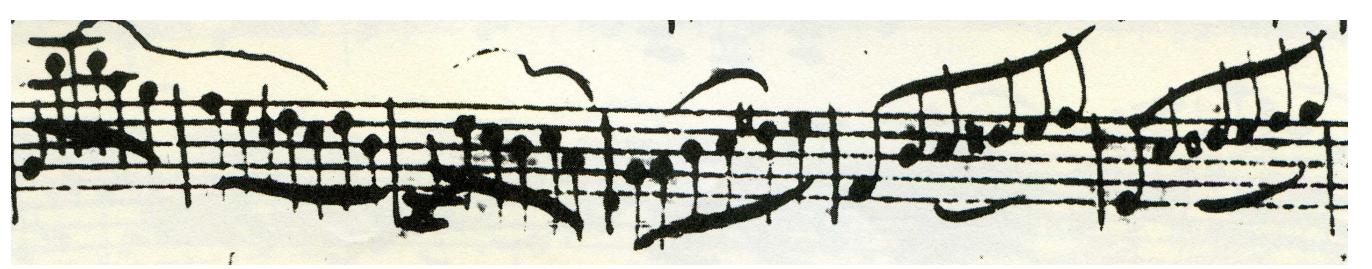

Ex. 7, Suite III Courante, measures 23-28 - Anna Magdalena Bach Manuscript

The gigues can be divided into three different types: the French Gigue, Giga I, and Giga II. The French gigue is characterized by a joyful lilt and a combination of balance and imbalance, which, in the fifth suite, is shown through imbalanced phrasing and bowings.

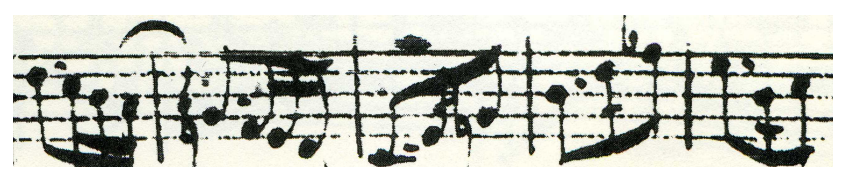

Ex. 8, Suite V Gigue, measures 65-69 - Anna Magdalena Bach Manuscript

The Giga I has a sprawling, triple feel, and appears in Bach's fourth suite with the eighth notes joined in groups of threes.

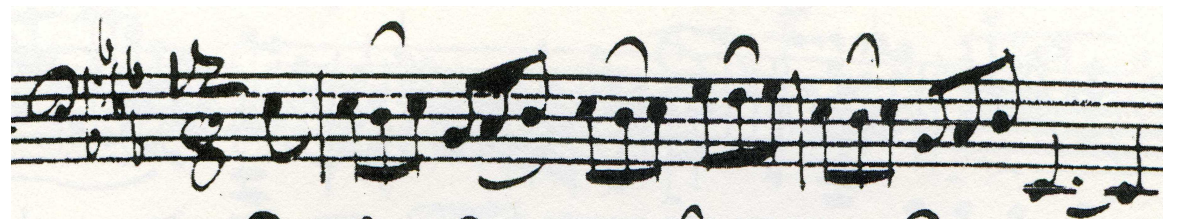

Ex. 9, Suite IV Gigue, meàsures 1-2 - Anna Magdalena Bach Manuscript

Giga II is used most often by Bach, and is found in the rest of the suites. It is the most different from an actual dance type, but has a very complex structure. 


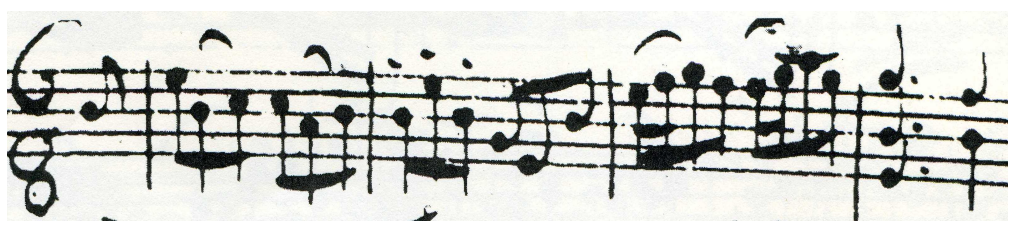

Ex. 10, Suite I Gigue, measures 1-4 - Anna Magdalena Bach Manuscript

Although this analysis may seem as if Bach's solo cello suites are simply academic renditions of dance music, this is simply not the case. Not only did Bach illustrate the cello's ability to portray a variety of dance styles, he also demonstrated the beauty of the violoncello as a solo instrument. Before this time, the cello was rarely used as a solo instrument, as Wijsman states, "The six solo suites of J.S. Bach... are anomalous in German music of the period, since music written specifically for solo cello before the middle of the eighteenth century is extremely rare" (755). The idea that Bach was the individual to compose such an innovative work for the cello is also surprising - "The six [cello] suites are important, because, according to Klaus Marx, they are the first solo works for cello written by someone who was not a cellist" (Little, 58). Again, Bach's appointment at Cöthen provided him the perfect opportunity to compose these unaccompanied suites. Bach's position was considerably more prestigious than his previous positions, and the wealth of Prince Leopold (the head at Cöthen) was ample and used profusely in the realm of the arts. As a result, Bach had some of the most talented instrumentalists at his disposal, not the least being the resident cellist.

Those who set the tone are the well-paid chamber musicians, some of whom receive substantial increases during Bach's time in office and who without doubt are one and all excellent soloists. It makes sense that [Prince] Leopold hires Christian Ferdinand Abel, an outstanding virtuoso on the cello and viola da gamba, for the prince plays the gamba himself (Geck, 103).

Because of the relationship that Bach likely had with this talented musician, the composer could easily discern the solo capabilities of the cello and write his suites accordingly. Interestingly enough, the sixth and last suite was most likely written for a viola da gamba (which has five strings as opposed to the four of a standard cello), implying that Bach took advantage of both of the instruments at which Abel was proficient.

Bach introduces the virtuosity of the cello to the public very progressively through the cycle of the suites. As Geck states, "At that time, solos for cello were still unusual, brand-new territory; so it is not surprising that he sets up the suite sequence as a Gradus ad Parnassum, at the beginning particularly mindful of the specifics of the instrument" (603). By "Gradus ad Parnassum" he means that Bach writes the suites as if he is writing a series of etudes, beginning simply and 
getting progressively more difficult, exemplifying more technical proficiency. Geck goes on to mention that, interestingly enough, the minuet of the first suite mimics a bass line that would have been familiar to any cellist of the time that had to play a continuo part.

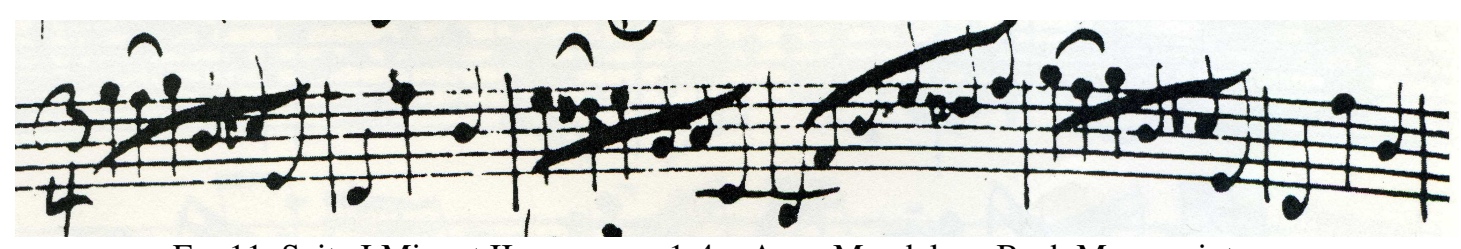

Ex. 11, Suite I Minuet II, measures 1-4 - Anna Magdalena Bach Manuscript

Progressively throughout the suites, though, Bach illustrates the harmonic and even polyphonic capabilities of the cello, beyond that of a simple bass line.

One solo line in the hands of Bach can be manipulated to create many different possibilities. Throughout the cello suites, Bach uses what is known as "implied counterpoint", where the movement of the piece implies more than one line of music. In this way, Bach takes the texture of monophony and creates the impression of polyphony within it. "[The cello suites] demonstrate Bach's command of performing techniques but also his ability to bring into play, without even an accompanying bass part, dense counterpoint and refined harmony with distinctive and well-articulated rhythmic designs, especially in the dance movements" (Wolff, 232). In the same way, Bach can also imply logical harmonic progressions. Williams speaks of Bach's "surefootedness that allows the solo works for violin or cello to follow, often by hints alone, the logic of good harmony while surprising and even momentarily puzzling the listener" (286). These hints of harmony in monody also go on to create sustained melodies as a result (Williams, 367). Part of the brilliance of Bach is his ability to create a melody that can stand independently, yet at the same time produce an impression of polyphony and tonal movement (Mellers, 35).

The brilliance that is demonstrated in Bach's works for cello led others to pursue compositions that demonstrated the virtuosity of the instrument. Bach's pioneering in the realm of composition for cello began a compositional explosion of cello works all across Western Europe. Many prominent composers, especially those who were not cellists, now felt more comfortable writing for this instrument.

While the cello was not used as a solo instrument in the majority of Western Europe, it must be mentioned that Italy was an exception to this rule. Even by the latter half of the seventeenth century, there is evidence that the cello had a solo role, which can be demonstrated by Domenico Gabrielli's seven Ricercares for solo cello (Schwemer, 10).

Other works also include the Antonii ricercares and the Bononcini sonatas (Barnett). Many of these works, however, were not published as stand-alone cello 
works, as they were often published in conjunction with flute or violin works. Also, many of them lacked structural connectivity or appeared to be merely etudes for the instrument. These composers were also all cellists. Bach, therefore, was not only the first German-speaking composer, he was also the first composer for the cello that was not a cellist himself, and he was the first to write an entire work for cello that was structurally sound, virtuosic, and stood on its own in publication.

Bach opened the door for composers who were from other countries, and who played other instruments, to write works for cello. Joseph Bordin de Boismortier, for example, was a French composer during the Baroque period who wrote concertos and sonatas for a variety of instruments, with numerous cello sonatas appearing after Bach's cello suite publications. Antonio Vivaldi, a prolific writer and violinist, wrote thirty concertos for the cello, around the time the Bach suites were published. However, they were not published until after Vivaldi's death because of the cello's limited solo role at the time of their composition (Gardner, BBC Review). Lesser known cello concertos include Bach's second son, Carl Philipp Emanuel Bach, who wrote three concertos for cello, and Leo Leonardo, who wrote six. Luigi Boccherini, a virtuoso cellist in his own right, wrote numerous cello concertos, the B-flat major concerto being an integral part of the standard cello repertoire today. Also staples of cello repertoire are Haydn's two cello concertos, one in C Major and one in D Major, written about forty or fifty years after Bach's cello suites. While some of these composers were cellists, many, like Boismortier and Vivaldi, were not, creating even more variety in the realm of cello repertoire. When this happened, composers from a variety of backgrounds and compositional styles could experiment by writing for cello.

Although the cello was an important instrument for many reasons before Bach's work, it is apparent that it was Bach's cello suites that started the proliferation of compositions for cello that exist for the instrument today. While a few pieces for cello as a stand-alone instrument existed before Bach's time, the amount of works in this genre increased exponentially after Bach published his suites.

What was it about Bach's cello suites that made them so uniquely suited to start this explosion of cello repertoire? As mentioned before, Bach's choice of dance suites were perfect in their portrayal of the cello in an environment in which it was already well known. Secondly, he used contrapuntal and rhythmic techniques to illustrate the harmonic and melodic powers of the instrument. Because of the blending of these two ideas, Bach created a work that looked to the future by looking back at the past. He created a work that was universally accessible to his audience by using well-known dance themes, and which showed what the cello would be capable of if future composers would only take advantage of it. 


\section{Bibliography}

Bach, Johann Sebastian. Six Suites for Unaccompanied Violoncello. 1727-1731. New York: Barenreiter, 2000.

Barnett, Gary. "Review." Review of Antonio Bononcini, Complete Sonatas for Violoncello and Basso Continuo, ed. by Lowell Lindgren. 1999. Journal of Seventeenth-Century Music. Society for Seventeenth-Century Music, 1999. http://sscm-jscm.press.illinois.edu/v5/no1/barnett.html (Accessed December 9, 2009).

Chiapusso, Jan. Bach’s World. Indianapolis: Indiana University Press, 1968.

Gardner, Charlotte. "A Performance Oozing soul and Individuality." Review of Antonio Vivaldi, Cello Concertos, Performed by Han-Na Chang. CD. BBC Music Beta. BBC, 22 Oct. 2008. http://www.bbc.co.uk/music/reviews/wh8c (Accessed December 10, 2009).

Geck, Martin. Johann Sebastian Bach: Life and Work. Orlando: Harcourt Books, 2000

Little, Meredith, and Natalie Jenne. Dance and the Music of J.S. Bach. Indianapolis: Indiana University Press, 1991.

Markevitch, Dmitry. "The Cello as an Accompanying Instrument in the Eighteenth Century." Strings 6.3 (1991)

Marckx, Leslie Hirt. “Inspired by Dance.” Strad 112.1333 (2001): 506-509.

Mellers, Wilfrid. Bach and the Dance of God. London: Faber and Faber Limited, 1980.

Shwemer, Bettina and Douglas Woodfull-Harris, eds. Six Suites à Violoncello Solo senza Basso: Text Volume. Basel: Barenreiter, 2000.

Spitta, Philipp. Johann Sebastian Bach: His Work and Influence on the Music of Germany, 1685-1750. New York: Dover Publications, 1951.

Waterman, Ruth. "Rhythm: The living, lilting pulse of dance." Strad 108.1284 (1997): 418-421.

Wijsman, Suzanne. "Violoncello." The New Grove Dictionary of Music and Musicians. 2nd ed. 2001. 
Williams, Peter. J.S. Bach: A Life in Music. New York: Cambridge University Press, 2007.

Wolff, Christoph. Johann Sebastian Bach: The Learned Musician. New York: W.W. Norton \& Company, 2000. 